\title{
FORENSIC ACCOUNTING IN FUNCTION OF PREVENTION AND FIGHT AGAINST CORRUPTION IN THE PUBLIC SECTOR
}

Duško Šnjegota ${ }^{1}$, Branka Milošević Šnjegota²

\author{
${ }^{1}$ Faculty of Economics University of \\ Banja Luka, \\ Banja Luka, Bosnia and Herzegovina \\ ${ }^{2}$ University of Business Studies in \\ Banja Luka, \\ Banja Luka, Bosnia and Herzegovina
}

\begin{abstract}
:
In recent times, corruption in public sector has been considered one of the biggest problems, that directly affects the stability of public finances and the functioning of the public sector in general, and therefore the economic stability of the country as a whole. Standard mechanisms of prevention of systematic corruption, among other things, represent different types of monitoring and control in the public sector, which are directed towards the facilitation of efficient and effective management of public funds.

In recent years, special emphasis in the fight against corruption has been placed on the role of police, and investigative and prosecutorial authorities as bodies primarily aimed at repression and strengthening of cooperation between these bodies and the authorities which are primarily focused on prevention in the system.

This paper attempts to answer the question whether, in our circumstances it would be appropriate to establish an entirely new public function - forensic accounting, which would deal with people with specific skills without which it is clearly not possible to make a good connection between prevention and repression.
\end{abstract}

Keywords:

public monitoring and control, corruption, law enforcement agencies, forensic accounting.

\section{INTRODUCTION}

According to the relevant literary sources, the term "forensic accounting" was used for the first time by Maurice E. Peloubet, a partner in the accounting firm Pogson, Peloubet \& Co from New York, in the article entitled "Forensic accounting: Its place in today's economy" in $1946 .{ }^{1}$

According to the American Institute of Certified Public Accountants (American Institute of Certified Public Accountants - AICPA) a service provided by forensic accountants implies a set of accounting, auditing, financial and research skills, and knowledge of legal regulations, which are used for the purposes of collecting, analyzing and evaluating evidence and presentation of research results to solve financial problems.

The Association of Certified Fraud Examiners (The Association of Certified Fraud Examiners - ACFE), defined forensic accounting as a discipline that is based on the use of accounting skills in civil or criminal cases, including generally accepted accounting and auditing principles, in order to determine the loss of profits, revenue, property or damage, estimate the effectiveness of system of internal control, fraud detection, or the performance of other activities that require the involvement of accounting expertise in the legal system.

The largest number of associations whose activities are connected with forensic accounting is registered in the United States. In addition to the AICPA and ACFE, Association of Certified Fraud Specialist (Association of Certified Fraud Specialists

\section{Duško Šnjegota}

e-mail:

dusko.snjegota@ef.unibl.org
1 See, for example, in Belak, V. (2011). Business forensics and forensic accounting, the fight against corruption, Belak excellens doo, Zagreb, 10. 
- ACFS), American College of Forensic Examiners (American College of Forensic Examiners - ACFE), Forensic Accounting Society of North America (Forensic Accounting Society of North America - FASN), The Network of independent Forensic Accountants (The Network of independent Forensic Accountants - NIFA) and others operate in the United States.

The European Office for the Fight against Fraud (Office Européen de Lutte Anti-fraude - OLAF) was established in 1999 in the European Union with the authority to investigate fraud and corruption that proved detrimental to the EU budget, as well as for its explicit policy designed to combat fraud.

The Anti-Fraud Coordinating Structures (Anti-Fraud Coordinating Structures - AFCOS) is an operationally independent authority which is formed at the level of Member States and which is responsible for the protection of EU financial interests against fraud and for providing assistance and support to OLAF.

In the Republic of Srpska and BIH, specially established bodies or organizations that would be responsible for promoting the development of the theory and practice of forensic accounting have not been founded so far. Also, it is not currently possible to identify a sufficiently clear commitment on the need to establish such public function or possible ways of its organization, which equally indicates how the application of forensic accounting applies in the real sector and the same way in the public sector. On the other hand, when it comes to the state of public finances and the public sector in general, there is a widely held public perception that a high level of corruption in different areas, such as public procurement, employment, allocation of public funds in the form of subsidies, grants, etc. exists. It demonstrates that there exists the need for implementation of some new, additional activities in relation to the already existing ones in the system, which would allow solving the accumulated problems. It is usually expected that these additional activities be entrusted to some of the existing public oversight bodies such as external public audit, although realistically this is not possible for various reasons.

The aim of research in this paper is to attempt to give an answer to the question whether, in our circumstances it should be appropriate to establish an entirely new public function such as forensic accounting, which would be led by people with specific knowledge and skills, and with whose action it would be possible to give new quality system of prevention of and fight against corruption.

2 Budimir, N. (2013). Forensic accounting. Business economists, No. $8 / 13,2$

3 www.aicpa.org

4 Adapted from: Petkovic, A. (2010). Forensic audit - fraud in the

\section{A SUMMARY OF TYPES, SCOPE AND POSSIBLE WAYS OF ESTABLISHING AND ORGANIZING THE FUNCTION OF FORENSIC ACCOUNTING}

The definition of forensic accounting encompasses fraud, fraud prevention and investigation of fraud. ${ }^{2}$ According to the classification $\mathrm{AICPA}^{3}$ in 1986 forensic accounting consists of two categories: investigative accounting and services of judicial support. Investigative accounting appears in the form of financial-criminal investigations and forensic audits, and judicial support services makes any professional support to lawyers in court proceedings by persons who are not lawyers by profession, in this case by forensic accountants.

Financial-criminal investigations are related to the involvement of people who investigate fraud and operate within the police and other agencies authorized to conduct investigative actions, inspection authorities, auditing firms, law enforcement etc. The main task of investigators who deal with financial-criminal investigations is not based on the use of specific knowledge and skills to recognize symptoms of fraud and to collect appropriate evidence of its existence.

Forensic auditing can be defined as a special service to audit financial statements, based on the application of accounting and audit techniques and skills, and targeted, focused and detailed, in-depth audit procedures, aimed at detecting criminal activities, whose effects can be recognized in the financial statements and reporting on these actions and their effects in a manner that is acceptable to the legal proceedings. ${ }^{4}$

Forensic accountant in legal proceedings can appear as a consultant or expert witness. As a consultant, that person can be examined by a lawyer for being a professional, who has the task of gathering and interpreting certain documentary evidence, preparing the analysis, consulting the lawyer, etc. Forensic accountant can be in the role of an expert witness or may be hired by the lawyer or summoned by the court as an expert witness to testify in court proceedings. In this case, forensic accountants are expected to express their opinion on trial.

The described methods of possible action and the role of forensic accountants based on classifications AICPA, in the existing organization of the investigative and judicial process in the Republic of Srpska and BIH could be partially identified as:

- the role of forensic accountants as persons responsible for running financial-criminal investigation best relates to the existing role of persons within competent police agencies working on criminal and other investigations, especially in the field of financial crime,

- forensic accountant as a person dealing with the forensic audit corresponds to the meaning of classical financial auditor, or a person who performs activities of audit of financial statements and audit compliance, although their activities are not identical, whereas 
- Forensic accountants as persons, that provide the most current judicial support can appear as a court expert, an economist or some other professional.

However, on the basis of these comparisons it cannot be reasonably concluded that the function of forensic accounting has in fact been already established, it is obvious that there are significant differences between forensic accountants and persons acting under the now recognizable roles and responsibilities (police inspectors, court experts, external auditors, etc.).
Although auditors have long been recognized as having an important role in detecting fraud, it is well known that they do not operate in a vacuum. ${ }^{5}$ Although their roles sometimes overlap, auditors of financial reports and forensic accountants deal with financial fraud issues from different viewpoints, usually using different information documented in different ways and for different purposes. ${ }^{6}$

As an illustration of the above, the following table lists some of the main similarities and differences between the classical (traditional) financial and forensic audits, based on competencies, standards and implementation methodologies that are obtained as audit evidence in the context of activities related with the audit of financial statements.

\begin{tabular}{|c|c|c|}
\hline Activity & Financial audit & Forensic accounting \\
\hline subject to review & The financial statements as a whole & $\begin{array}{l}\text { The financial statements, with a focus } \\
\text { on certain parts }\end{array}$ \\
\hline The scope of the audit & Sample & $\begin{array}{c}\text { All or most of the transactions related to } \\
\text { activities that are the subject of } \\
\text { investigation }\end{array}$ \\
\hline Rating significance transactions & $\begin{array}{l}\text { Based on the threshold of materiality } \\
\text { and material transactions }\end{array}$ & $\begin{array}{c}\text { Any transaction related to the fraud } \\
\text { being investigated is important for } \\
\text { auditors }\end{array}$ \\
\hline Audit evidence & $\begin{array}{c}\text { Mostly based on standard accounting } \\
\text { and other business documents of } \\
\text { the auditee }\end{array}$ & $\begin{array}{l}\text { In addition, it includes the evidence } \\
\text { received from various external sources }\end{array}$ \\
\hline auditing standards & $\begin{array}{l}\text { Fortified law and international } \\
\text { auditing standards }\end{array}$ & $\begin{array}{l}\text { Relatively informal set of standards and } \\
\text { principles, primarily based on knowl- } \\
\text { edge, experience and skill of auditors }\end{array}$ \\
\hline Time spent on audit & One business year & $\begin{array}{l}\text { The time period that last for over } \\
\text { several years }\end{array}$ \\
\hline reporting & $\begin{array}{l}\text { The auditor's opinion on the financial } \\
\text { statements and on compliance }\end{array}$ & $\begin{array}{l}\text { Statement of committing fraud, and } \\
\text { identify the circumstances, } \\
\text { the perpetrator, damage, etc. }\end{array}$ \\
\hline time conducting audits & $\begin{array}{c}\text { Period encompassing several months at } \\
\text { the end audited and the beginning } \\
\text { of next year }\end{array}$ & $\begin{array}{l}\text { Typically significantly longer compared } \\
\text { to traditional financial audit }\end{array}$ \\
\hline Cost of audit & $\begin{array}{l}\text { Usually relatively low, especially in the } \\
\text { case of the so-called commercial } \\
\text { auditors in local conditions }\end{array}$ & $\begin{array}{l}\text { Significantly higher compared to } \\
\text { traditional external audit }\end{array}$ \\
\hline
\end{tabular}

Source: author's treatment

Responsibilities and powers of court experts stipulate the applicable law and, as a rule, there are no specially formalized professional standards related to the area of judicial expertise. For example, according to the provisions of the Law on Experts of the Republic of Srpska ${ }^{7}$, special conditions for

5 Golden, T.W., Skalak, S.L., Clayton, M.M. (2006). A guide to forensic accounting investigation. John Wiley \& Sons, Inc., Hoboken, New Jersey, 33

6 Mikerevic, D. and other (2013). Forensic of business. "Finrar" d.o.o. Banja Luka, 19 the appointment of experts in the Republic of Srpska are as follows: the candidate to be hired as a court expert needs to holda university degree or to have completed the first cycle of studies in the duration of four years and to have obtained at least 240 ECTS credits or equivalent, to have at least five years of professional experience in the areas specified in the request for the appointment and must not perform activities that are incompatible with business experts. A person who is

7 Official Gazette of the Republic of Srpska, No. 74/17 
appointed as a court expert is required to develop professionally, through a program organized by the Ministry of Justice. Some other specific double determinants of expert witnesses and their professional work have not been specified yet, therefore, it can be concluded that the conventional comparison of the expert witness to forensic accountant is practically groundless.

Organizational function of forensic accounting in the public sector can be established through a variety of models, including a model of engaging a forensic accountant in the activities of the prosecution, the model that engages forensic accountants in specific, independent professional organizations, a model that is a combination of the previous two and others.

As regards a potential model for the involvement of forensic accountants in the public sector, some protagonists of the idea of the need to establish the functions of forensic accounting, see the possibility of their involvement in the activities of the supreme audit institution. Each country has a mandate to conduct audit of budget beneficiaries, public enterprises, public institutions and other entities in the public sector. Forensic accountants, of course, can be engaged by the independent audit firms in the event that they have a legal mandate and economic interest to provide forensic audit.

In the case of forensic investigation as an integral part of the overall activity and investigation bodies (the appropriate police agency, etc.), it is important to note that, as such, these bodies are not something of a novelty, although it can be seen, that the term of forensics usually denotes investigation of the circumstances in which serious crimes have been committed, such as murder and others. At the same time, research of the circumstances and consequences of criminal offenses that had been committed in the area of economic crime are essentially nothing but forensic research activities, although usually they are not called by that name.

The basic assumption for the organization of forensic accountants in independent professional organizations refers to a clear legal determination of the conditions for its establishment and funding, then earning of the professional title of forensic accountants, the establishment of a public register of forensic accountants, defining conditions for their professional engagement, establishing clear rules for their continuous education and training, etc.

The combination of the previous two models of organization of forensic accountants would make sense in the context of creating conditions for quality competition and confrontation of different professional opinions about these actions and activities that are the subject of forensic investigations, which would have a positive impact on the quality of the profession and strengthen the de facto independence of a forensic accountant.

8 It is the ISSAI framework of the auditing standards, principles and guidelines established by the International Organization of Supreme Audit Institutions (INTOSAI) - more about these standards
When it comes to hiring forensic accountants under the auspices of the Supreme Audit Institution it is important to note that such a model of their organization is not recognized by the relevant auditing standards that underpin the work of these audit institutions. ${ }^{8}$

\section{REASONS FOR THE ESTABLISHMENT OF FUNCTION OF FORENSIC ACCOUNTING IN THE PUBLIC SECTOR}

The reasons for the development of forensic accounting are numerous, and the main reasons are the lack of specialized knowledge and experience of internal and external auditors, inspectors and accountants during the investigation and other illegal activities, as well as due to the expert opinion on legal, business and other needs. ${ }^{9}$

The public sector in each country includes a number of public subjects of different legal forms and forms of organization which have been assigned the rights, responsibilities and powers in order to provide quality public services (operators of special public importance, ministries, departments, directorates, agencies, public institutions, public enterprises etc.) and which, directly or indirectly manage large quantities of financial and other public funds. In order to control these subjects, the state on its part establishes different control mechanisms whose main objective is to ensure the legality, efficiency and effectiveness in the functioning of the entire system. The backbone of the system of public oversight and control of today, mainly consists of internal and external audits, as well as traditional inspection bodies, such as budget inspection.

However, as expected by the public, these mechanisms cannot provide a sufficient level of protection of public interest or protection against misuse of public funds. For example, research conducted by the ACFE shows that the external audit reveals only about $11.0 \%$ of criminal acts ${ }^{10}$, while in domestic conditions it is quite certain that the contribution of the internal audit process of prevention and detection of such actions is much smaller. It is pointless to discuss the significance, role and achievements of budget inspection.

Special emphasis in the fight against corruption in recent years should be put on the role of the police, and investigative and prosecutorial authorities, as bodies primarily aimed at repression and prosecution of perpetrators of corruption and other illegal activities, and at strengthening cooperation between these and the bodies, that are primarily focused on prevention in the system, and the creation of a system whose mechanisms is going to prevent the occurrence of fraud or risk of their occurrence should be reduced to a minimum level.

9 Budimir, N. (2013). Forensic accounting. Business economists, No. $8 / 13,2$

10 Singleton, T.W., Singleton, A.J., Bologa, J., Lindquist, R. (2010). Revision of criminal actions and forensic accounting, translation of the Association of Accountants and Auditors of Serbia, Belgrade, 23. 
It is widely held that authorities and bodies responsible for public oversight and control in the management of public funds, regardless of the fact that as such they are generally directed towards a system and not to the person (individual) who operates the system, should be in the role of direct accomplices investigation and prosecution, or in the role of someone who through their daily work reveals, and therefore reports the corruption and other criminal activities.

Without denying the obligation of all persons acting in public interest (as external and internal auditors certainly do), it should be noted that (audit) principles and standards are not designed as tools that could not be efficiently used for this purpose.

If the above is true, a perfectly logical question arises how in the management of public funds in the context of prevention and fight against corruption, is it possible to make a connection between prevention and repression, between organs and bodies which are primarily engaged in the system and those who are primarily concerned with persons that manage or otherwise operate the system? It seems that it is an important issue for a forensic accountant to address.

Otherwise, various anomalies which appear in the management of public funds could be classified into two main groups - an error or a fraud. The key difference between them is that the latter, unlike the former, is committed knowingly and on purpose. Scams are actions that are illegal and made in secret in order to obtain a material benefit to the perpetrator, to the detriment of a public subjects or public interest.

Frauds in the public sector appear in three basic forms - misleading financial reporting, corruption and misappropriation of public funds. According to the ACFE research conducted in the USA in the period from 2010 to 2014, the misappropriation of funds was the most common offence, followed by misleading financial reporting, although it is quite rare, but has the greatest consequences and causes the greatest material damage. ${ }^{11}$ Perception of domestic and foreign publicity leads to the conclusion that in the domestic circumstances, corruption is the most common form of fraud, and that, as such, it strongly affected all segments of society, especially the public sector. Corruption as a form of fraud occurs in different forms, through the conflict of interest, bribery, illegal gratuities and gifts, and economic blackmail. ${ }^{12}$

A special area of public sector that is frequently involved in corruption is the public procurement of goods and services, but we should not neglect the processes of hiring, granting of subsidies, grants and other similar support to subjects or individuals and others. If, for example, the possible role of forensic accountants was to be considered in the context of prevention and fight against corruption in public procurement, the scope of their activities and relationships

11 More about this can be found on www.acfe.com/rttn/docs/2014report-to-nations-charts-and-graphs.pdf

12 Belak, V. (2011). Quoted work, 36 with others in the system responsible for the prevention and repression could be presented as follows:

- the establishment of a legal, transparent, efficient and effective system of public procurement in a public subject presents a direct responsibility of management,

- internal auditors (if the internal audit function in the reporting subject is established) monitor and review the system of internal controls and with their advice help the management, that in this case the (sub) system of public procurement functions in accordance with the principles promoted through the regulations of public procurement and other regulations underpinning the system of management of public funds,

- in accordance with the principles underlying the system of Public Internal Financial Control (PIFC) ${ }^{13}$, internal auditors have a duty to inform all managers of all illegal activities that are detected, and the responsibility for reporting such acts and their perpetrators to the law enforcement rests with the management and leadership ${ }^{14}$,

- external public auditors, generally, audit operations in public sector, give an independent opinion on the financial statements audited and ensure the operations comply with the statute and other regulations, and evaluate cost-effectiveness for performance audits, assess efficiency and effectiveness of operations of the program and projects implemented in the public sector; among other things, external auditors cooperate with them and work in coordination with the internal auditors,

- depending on the adopted regulatory framework and models of external public audit, external auditors have a responsibility to inform the authorities about corruption and other criminal activities detected during the audit, but it is not the main or primary purpose of their establishment and operation, as public external audit is an instrument of parliamentary control and directly controls the functions carried out by the legislative over the executive bodies,

- in the present environment, forensic accountants may appear in the role of an investigator or forensic auditors, provided that their research is based on circumstantial evidence of possible fraud identified through the activities of internal and external auditors, with the aim that the occurrence of fraud in case it had actually occurred is documented, the damage caused

13 PIFC - Public Internal Financial Control

14 For example, under the system of internal financial controls in the public sector of the Republic of Srpska, the internal auditor is obliged to inform the head of the internal audit, if during the audit a suspicion that a criminal offense or misdemeanor had been committed, while the Head of Internal Audit has an obligation to inform the head of the entity of the irregularities and the elements that indicate the offense. 
on the grounds of fraud is assessed and law enforcement authorities are adequately informed about the results of their work,

- Forensic accountants would be also defined in this case as the most authoritative financial experts, who could provide appropriate services to support the court, similar to expert witnesses, who are within their legal mandate only invited to describe in a professional manner, that what they have acquired during their expertise,

- Finally, effective action of experts such as forensic accountants would surely have a positive impact on the system of preventing or reducing the risk of the occurrence of acts of corruption and fraud associated with them.

According to Belak ${ }^{15}$, forensic accountants may appear in the role of government inspectors - forensics, internal auditors - forensics, forensic accounting and commercial court experts.

In the modeled presentation, a possible role of forensic accountant is detecting fraud and preventing their occurrence in public procurement procedures. Forensic accountants are considered to be persons, who work with them and use the results of other relatively related professionals, such as internal and external auditors, but their mandate does not interfere with the mandate of such persons. It is believed that synchronized, systemic and multidisciplinary approach to establishing a system of prevention and fight against corruption could give much better results, than the approach which would occur as a result of certain intermingling of powers and responsibilities of the different agents involved in the system.

\section{CONCLUSION}

Forensic accounting is a profession whose systematical establishing in national circumstances generally speaking is still a stage in the process. Although some broad outlines of the profession can now be seen in the activities of persons in charge of public oversight and control, or in investigation conducted in order to detect and prove corruption and other criminal acts in the system. In the context of supporting the activities of prevention and fight against corruption, despite the obvious need for an established system, a new one needs to be built in the developed world; currently results of already existing public mechanisms of monitoring and control such as, for example, a public external audit are required.

It seems that the establishment of a system of forensic accounting functions will hardly be provided for, unless we firstly encourage an intense public debate about the importance of this function and its possible contribution to discovering and documenting various criminal acts and the damage that occurs with their perpetration. In this context, this debate needs to be encouraged in the legislative and other institutions of the system, but also in the respective higher education institutions as well as in the framework of the existing professional associations that bring together experts from related professions.

If we take a look on the strongly expressed perception and the existence of high levels of crime and corruption in the public sector that has so far at least partially been proved, it is easy to conclude that the benefits of establishing a forensic accounting could far outweigh the costs of its introduction into the system.

Active participation of forensic accountants in the system of prevention and fight against corruption in the public sector would not decrease the role and significance of the existing mechanisms of public oversight and control (external and internal auditors, budget inspection, etc.). On the contrary, it contributes to the better understanding of the real role of these mechanisms in the system and to the increase in the value of the results achieved through their functioning. This is especially important, owing to the fact that these results are not currently used to a sufficient extent by those they are primarily intended for.

In the context of everything stated above, by introducing forensic accounting into the processes of research and proving corruption and other criminal activities in the public sector, it would be possible to make a quality connection between prevention and repression, that is, ensure that the effectiveness in processing of the already committed crimes maximizes the risk of the occurrence of new ones. Therefore, forensic accounting would become a purposeful public function, the establishment of which would be fully justified.

\section{LITERATURE}

Mikerevic, D. and other (2013). Forensic of business. "Finrar" d.o.o. Banja Luka, 544 pages,

Budimir, N. (2013). Forensic accounting. Business economists, No. 8/13, pp 1-16,

Belak, V. (2011). Business forensics and forensic accounting, the fight against corruption. Belak excellens doo, Zagreb, 321 pages,

Petkovic, A. (2010). Forensic audit - fraud in the financial statements. "Proleter" d.oo. Bečej, 312 pages,

Singleton, T.W., Singleton, A.J., Bologa, J., Lindquist, R. (2010). Revision of criminal actions and forensic accounting. Translation of the Association of Accountants and Auditors of Serbia, Belgrade, 324 pages,

Golden, T.W., Skalak, S.L., Clayton, M.M. (2006). A guide to forensic accounting investigation. John Wiley \& Sons, Inc., Hoboken, New Jersey, 565 pages,

Law of the Republic of Srpska experts. Official Gazette of the Republic of Srpska, No. 74/17, 
Law on the system of internal financial controls in the public sector of the Republic of Srpska Gazette of the Republic of Srpska, No. 91/16, www.aicpa.org,

www.acfe.com,

www.issai.org. 